\author{
Mirosław ŚMIESZEK ${ }^{1}$ \\ Magdalena DOBRZAŃSKA ${ }^{2}$ \\ Pawel DOBRZAŃSKI ${ }^{3}$
}

\title{
ANALIZA ZMIAN W TRANSPORCIE PUBLICZNYM UNII EUROPEJSKIEJ NA PRZYKLADZIE WYBRANYCH MIAST
}

\begin{abstract}
Potrzeby transportowe należą do potrzeb wtórnych człowieka i są związane z różnym rozmieszczeniem przestrzennym zasobów, skupisk ludzkich i miejsc pracy. Rozwój gospodarczy jest ściśle uzależniony od infrastruktury transportowej i możliwości transportowych. Transport dotyczy zarówno przemieszczania ładunków, jak i ludności. W miastach szczególnie istotny jest transport osób, zwany często transportem publicznym. Rozwój miast zarówno pod względem liczby ludności, jak i ich powierzchni generuje wzrost potrzeb transportowych. Dodatkowo rozwój gospodarczy wymaga coraz to większej aktywności ludzi i ich mobilności. Miejski transport pasażerski w znacznym stopniu opiera się na prywatnych samochodach osobowych, które posiadają konwencjonalny układ napędowy. Wzrastająca liczba podróży tymi środkami komunikacji przyczynia się do powstawania zatorów komunikacyjnych i wzrostu zanieczyszczenia atmosfery $\mathrm{w}$ obszarach miejskich przez emisję gazów pochodzących ze spalania produktów naftowych. Oba te czynniki i hałas powodowany ruchem pojazdów przyczyniają się do obniżenia komfortu życia. Jednym ze sposobów ograniczenia tych niekorzystnych tendencji jest przejście na bardziej zrównoważony system mobilności, jakim jest zbiorowy transport pasażerski. Podejście to jest zgodne $\mathrm{z}$ aktualnymi wytycznymi Unii Europejskiej mającymi za zadanie ochronę środowiska i oszczędności pierwotnych źródeł energii, promującymi rozwój zrównoważonego transportu i odnawialne źródła energii. Głównym celem pracy jest przedstawienie zmian zachodzących w funkcjonowaniu transportu pasażerskiego w krajach Unii Europejskiej oraz ukazanie na przykładzie dwóch wybranych miast średniej wielkości stopnia realizacji polityki transportowej zmierzającej do rozwoju zrównoważonego transportu miejskiego.

Slowa kluczowe: transport publiczny, polityka transportowa, organizacja transportu publicznego.
\end{abstract}

\section{WPROWADZENIE}

W miastach Europy, zamieszkuje około 70\% ludności Unii Europejskiej. Mieszkańcy miast wytwarzają około $80 \%$ PKB Unii ${ }^{4}$. Prawidłowe funkcjonowanie tych miast i zapewnienie możliwości ich dalszego rozwoju gospodarczego wymagają odpowiedniej infrastruktury transportowej i mobilności ich mieszkańców. Mobilność w miastach staje się jednak coraz trudniejsza i coraz mniej efektywna. Nadal w wielu miastach jako podstawowy środek transportu wykorzystywane są pojazdy prywatne o napędzie konwencjonalnym.

\footnotetext{
${ }^{1}$ Dr hab. inż. Mirosław Śmieszek, prof. PRz, Katedra Metod Ilościowych, Politechnika Rzeszowska, Rzeszów, autor korespondencyjny: e-mail: msmieszk@prz.edu.pl

${ }^{2}$ Dr inż. Magdalena Dobrzańska, Katedra Metod Ilościowych, Politechnika Rzeszowska, Rzeszów

${ }^{3}$ Dr inż. Paweł Dobrzański, Zakład Informatyki w Zarządzaniu, Politechnika Rzeszowska, Rzeszów

${ }^{4}$ European Commission Report Brussels, 17.12.2013COM (2013) 913 final.
} 
Problemem wielu miast europejskich są notoryczne zatory komunikacyjne, których koszt osiąga znaczące rozmiary ${ }^{5}$. Obszary miejskie mają również wysoki udział w całkowitych emisjach $\mathrm{CO}_{2}$ pochodzących z działalności transportowej, który wynosi około $23 \%$. Zgodnie z wytycznymi UE miasta muszą spotęgować wysiłki, aby odwrócić niekorzystne tendencje w zużyciu paliwa i emisji składników toksycznych. Przepisy unijne dotyczące jakości powietrza oraz coraz bardziej rygorystyczne normy emisji dla pojazdów drogowych mają za zadanie zapewnienie ochrony obywateli przed narażeniem na szkodliwe skutki zanieczyszczeń powietrza i pyłu zawieszonego. Celem tych wysiłków powinno być osiągnięcie 60procentowej redukcji emisji gazów cieplarnianych. Ze względu na dużą gęstość zaludnienia w miastach oraz wysoki poziom ruchu na trasach o niewielkich długościach system transportu publicznego jest preferowanym rozwiązaniem ${ }^{6}$. Daje on większe możliwości redukcji całkowitej emisji składników toksycznych w mieście w porównaniu $\mathrm{z}$ transportem realizowanym za pomocą samochodów osobowych wyposażonych w konwencjonalne układy napędowe. W ramach polityki unijnej duży nacisk kładziony jest na wykorzystanie odnawialnych źródeł energetycznych w transporcie pasażerskim oraz preferowanie takich form transportu jak transport rowerowy. Wszystkie te zabiegi wymagają jednak sporych nakładów finansowych i zmiany w mentalności mieszkańców. Polityka UE nakreśla kierunki tych zmian. Stopień zaawansowania tych zaleceń nie jest jednakowy we wszystkich państwach członkowskich oraz ich miastach. Ogólnie można stwierdzić, że im bogatsze państwo, tym polityka proekologiczna $\mathrm{w}$ transporcie publicznym jest bardziej rozwinięta i są bardziej zaawansowane wprowadzone zmiany, których celem jest rozwój zrównoważonego transportu. Jednym $\mathrm{z}$ głównych celów pracy jest ocena zmian zachodzących $\mathrm{w}$ transporcie pasażerskim $\mathrm{w}$ krajach UE na przykładzie dwóch wybranych miast średniej wielkości o różnych stopniach rozwoju gospodarczego. Za wzorzec do porównania posłużyło szwedzkie miasto Linköping charakteryzujące się wysokim stopniem rozwoju. Drugim z rozpatrywanych w porównaniu miast jest Rzeszów, którego poziom rozwoju gospodarczego jest znacznie niższy, ale miasto to charakteryzuje się dużą dynamiką rozwojową.

\section{PRZEGLĄD WYBRANYCH DANYCH ZWIĄZANYCH Z DZIAŁALNOŚCIĄ TRANSPORTU PUBLICZNEGO}

Coraz bardziej rygorystyczne ustawodawstwo UE przyczynia się do spadku emisji szkodliwych substancji przez środki transportu drogowego. Zmiany w całkowitej emisji dla 19 krajów będących członkami UE przed rokiem 2005 pokazano na rysunku 1a. Na rysunku widoczna jest wyraźna tendencja spadkowa w wielkości emisji. Dla porównania Polska (rys. 1b) w obszarze tym ma jeszcze wiele do zrobienia ${ }^{7}$. Ostatnie trzy lata 2010-2012 (rys. 1b) dają nadzieję, że i w Polsce rozpoczął się okres korzystnych zmian. Natomiast dla Szwecji (rys. 1b) poza latami 2009-2010 zauważalna jest ciągła tendencja spadkowa w wielkości emisji szkodliwych substancji.

\footnotetext{
${ }^{5}$ L. Mussone, S. Grant-Muller, J. Laird, Sensitivity analysis of traffic congestion costs in a network under a charging policy, „Case Studies on Transport Policy” 2015/3; European Commission Report Brussels, 17.12.2013COM (2013) 913 final.

${ }^{6}$ R. Prud'homme, M. Koning, L. Lenormand, A. Fehr, Public transport congestion costs: The case of the Paris subway, ,Transport Policy” 2012/21.

${ }^{7} \mathrm{http} / / / \mathrm{ec}$. europa.eu/eurostat.
} 
Rys. 1. Emisja ekwiwalentu $\mathrm{CO}_{2}$ w krajach a) UE19, b) Polski, Szwecji
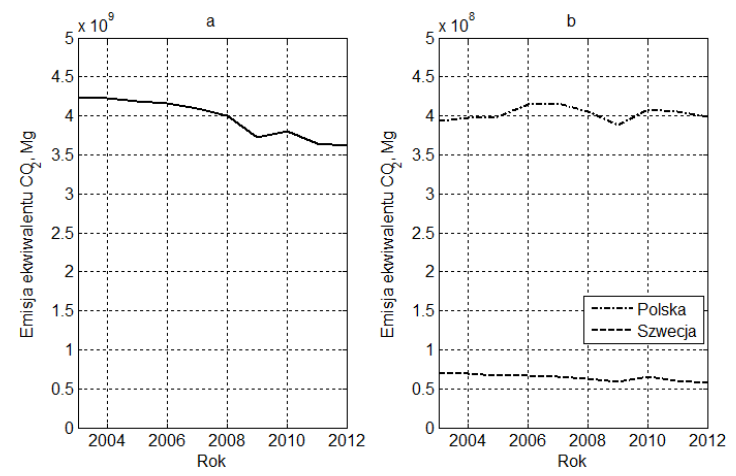

Źródło: opracowanie własne na podstawie http://ec.europa.eu/eurostat.

Emisja zanieczyszczeń i gazów cieplarnianych związana jest z ilością zużytych paliw ropopochodnych. Zmiany zachodzące w zużyciu paliw pokazane na rysunku 2 mają przebiegi o podobnym charakterze jak na rysunku 1 pod względem emisji.

Rys. 2. Zużycie paliw ropopochodnych a) w krajach UE19, b) w Polsce
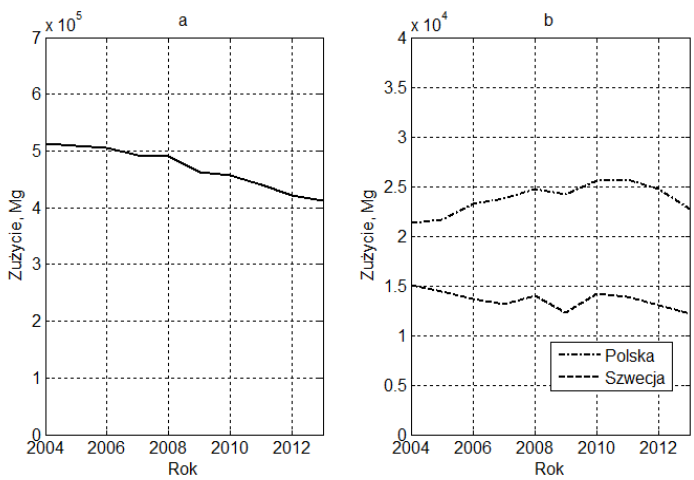

Źródło: opracowanie własne na podstawie http://ec.europa.eu/eurostat.

Transport drogowy osób ma znaczny udział w całkowitym zużyciu paliwa. Na transport ten składają się przewozy realizowane przez transport autobusowy i samochody osobowe. Wykresy zamieszczone na rysunku 3 pokazują, że zarówno w krajach UE, jak i w Polsce następuje spadek przewozów autobusowych wyrażony w pasażerokilometrach i jednocześnie zachodzi wzrost przewozów realizowanych samochodami osobowymi. Podobnie sytuacja przedstawia się w Szwecji. Wzrost ten dla krajów UE jest niewielki. W wypadku UE wzrost przewozów realizowanych samochodami osobowymi, porównując rok 2000 z 2012, wynosi 6\%. Największy wzrost obserwowany jest dla Polski i jest równy ponad 50\%, natomiast w Szwecji $-8 \%$.W wypadku Wielkiej Brytanii, Niemiec i Francji wynosi 1-8\% ${ }^{8}$. Biorąc pod

\footnotetext{
${ }^{8}$ EU transport in figures, Statistical Pocketbook 2014; EU transport in figures, Statistical Pocketbook 2015.
} 
uwagę przewozy autobusowe, obserwowany spadek w analizowanym okresie wynosi dla UE 4\%, Polski - ponad 30\% natomiast Szwecji - prawie 9\%.

Rys. 3. Przewozy w pasażerokilometrach realizowane przez transport autobusowy i samochody osobowe dla a) wszystkich krajów UE, b) Polski, c) Szwecji
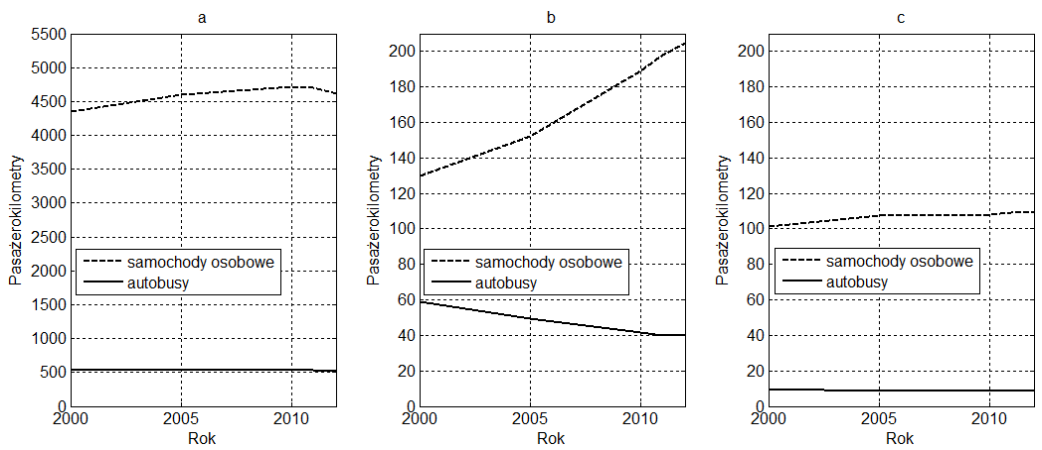

Źródło: opracowanie własne na podstawie EU transport in figures, Statistical Pocketbook 2015.

Zachodzące zmiany są szczególnie niekorzystne w Polsce. Analizując dane statystyczne ${ }^{9}$ dotyczące poszczególnych regionów i miast Polski, można stwierdzić, że spadek przewozów w komunikacji publicznej dotyczył wszystkich miast poniżej 500 tys. mieszkańców. Aby rozpoznać skalę problemu, postanowiono przeanalizować funkcjonowanie komunikacji publicznej w wybranych miastach UE o średniej liczbie mieszkańców.

\section{ANALIZA FUNKCJONOWANIA KOMUNIKACJI MIEJSKIEJ W RZESZOWIE}

Rzeszów jest miastem wojewódzkim leżącym w południowo-wschodniej Polsce. Ma $116,32 \mathrm{~km}^{2}$ powierzchni i liczy ponad 184 tys. mieszkańców. Miasto to jest stolicą województwa podkarpackiego i zarazem ważnym ośrodkiem gospodarczym, handlowym, przemysłowym, kulturalnym i akademickim. Miasto jest położone na skrzyżowaniu istotnych drogowych szlaków komunikacyjnych, blisko granic ze Słowacją i Ukrainą. Rzeszów ma wyraźnie ukształtowaną strefę zabudowy śródmiejskiej, która ma układ promienistokoncentryczny, dzielnice przemysłowe i mieszkaniowe są widocznie rozgraniczone. Gęstość zaludnienia w Rzeszowie należy do najniższych w Polsce wśród miast średniej wielkości. W ostatnich latach nastąpił wzrost liczby mieszkańców i liczby zarejestrowanych pojazdów osobowych $^{10}$ (rys. 4). Wraz z rozwojem ludności następował wzrost obszaru miasta i tym samym zwiększały się długości tras niezbędnych do pokonania między miejscem zamieszkania a celem podróży.

\footnotetext{
${ }^{9} \mathrm{http}: / /$ ec.europa.eu/eurostat.

${ }^{10} \mathrm{http}: / /$ stat.gov.pl/.
} 
Rys. 4. Wybrane wskaźniki charakteryzujące miasto Rzeszów a) liczba mieszkańców, b) liczba samochodów osobowych
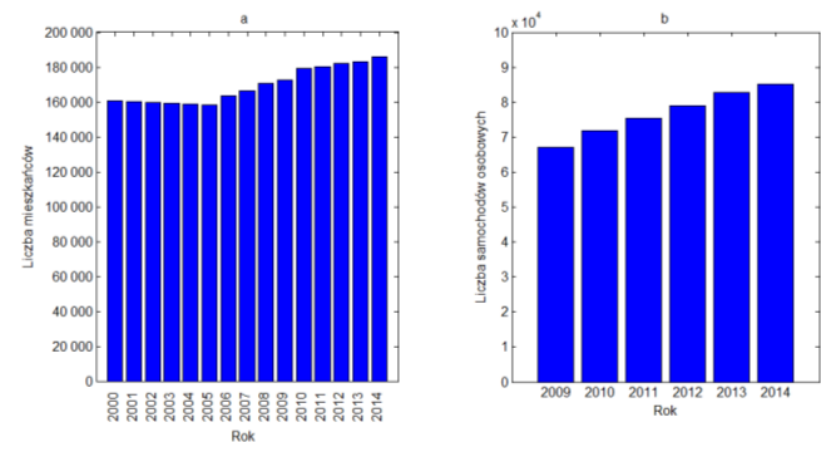

Źródło: opracowanie własne na podstawie http://stat.gov.pl/.

$\mathrm{Na}$ terenie Rzeszowa potrzeby transportowe zaspokajane są przez transport publiczny i indywidualny. W wypadku transportu publicznego najważniejsza jest komunikacja miejska podlegająca zarządowi miasta. Rzeszowska komunikacja publiczna w grudniu 2014 r. składała się z 46 linii autobusowych zwykłych, 3 linii specjalnych oraz 3 linii nocnych ${ }^{11}$. W ramach tej komunikacji można wyróżnić 6 linii o znaczeniu priorytetowym, których częstotliwość kursowania w godzinach szczytu wynosi 10-15 minut, oraz grupę linii podstawowych kursujących co 20-30 minut oraz uzupełniające. Przez teren miasta przebiegają również linie komunikacyjne innych przewoźników. Skupiają się oni jednak wyłącznie na dowozie pasażerów do Rzeszowa i można przyjąć, że nie biorą udziału w zaspokajaniu potrzeb transportowych na terenie miasta. Jak w większości polskich miast można zaobserwować tu spadek przewozów komunikacją publiczną i wzrost zarówno liczby samochodów osobowych, jak i nasycenia tymi pojazdami (rys. 5) ${ }^{12}$.

Rys. 5. a) Przewozy komunikacją publiczną i b) nasycenie samochodami osobowymi
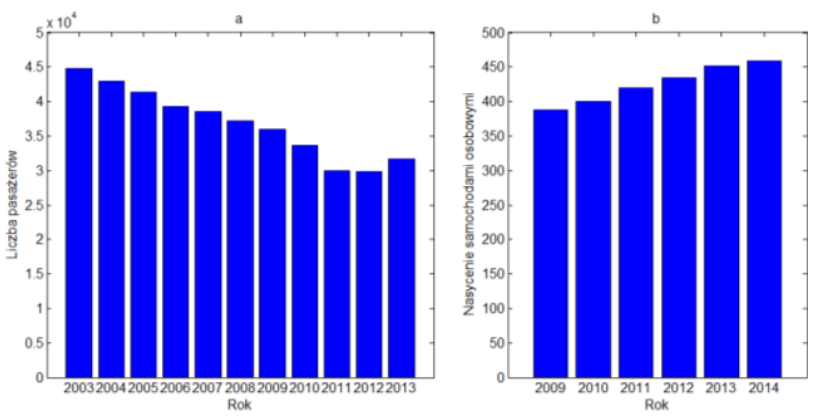

Źródło: opracowanie własne na podstawie http://stat.gov.pl/.

\footnotetext{
${ }^{11}$ M. Śmieszek, M. Dobrzańska, P. Dobrzański, Analiza czasów przejazdu wybranej linii komunikacji miejskiej w Rzeszowie, „Logistyka” 2015/4.

${ }^{12}$ Ibidem.
} 
Zaobserwowany spadek w przewozach komunikacji publicznej zachodzi przy wzroście liczby mieszkańców. Rosnące wraz ze wzrostem liczby mieszkańców potrzeby przewozowe są zaspokajane przez transport indywidualny. Jest to tendencja niekorzystna z punktu widzenia zużycia energii i emisji szkodliwych substancji.

W ramach pracy przeprowadzono badania funkcjonowania komunikacji miejskiej. Skupiono się $\mathrm{w}$ nich na jednej wybranej linii komunikacji miejskiej w każdym $\mathrm{Z}$ analizowanych miast. W wypadku Rzeszowa analizie poddano linię 0B, która jako jedna $\mathrm{z}$ sześciu należy do grupy linii priorytetowych. Linia ta charakteryzuje się ruchem okrężnym jednokierunkowym wokół centrum miasta. Jej początek i koniec znajdują się w sąsiedztwie dworca kolejowego PKP. Przeciwny kierunek jest obsługiwany przez linię $0 \mathrm{~A}$. Na obu liniach kursują w większości nowoczesne dwuosiowe autobusy niskopodłogowe. Wzdłuż trasy przejazdu znajdują się główne centra handlowe Rzeszowa, dwie wyższe uczelnie wraz z osiedlami studenckimi i największy zakład przemysłowy Rzeszowa. Na trasie linii znajduje się 19 przystanków. Przebieg linii 0B oraz wykaz przystanków i odległości pomiędzy nimi przedstawiono na rysunkach 6 i 7.

Rys. 6. Przebieg linii 0B na terenie Rzeszowa wraz z umiejscowionymi na jej trasie przystankami

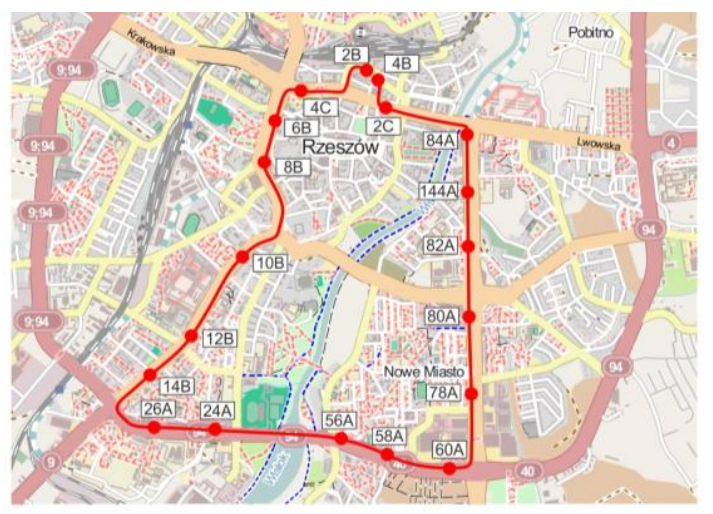

Źródło: opracowanie własne.

Rys. 7. Odległości między przystankami linii 0B

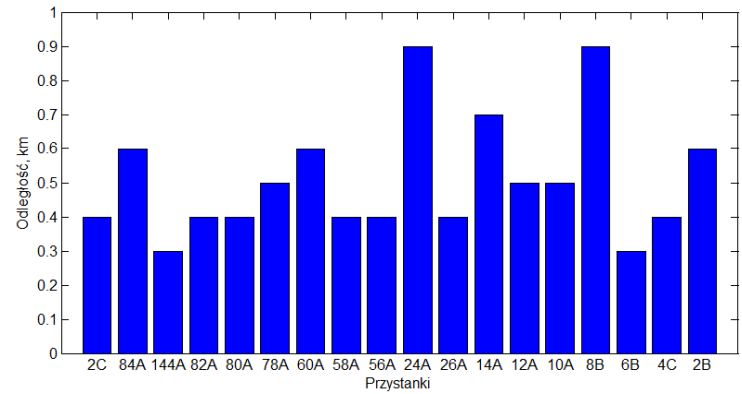

Źródło: opracowanie własne.

Badania wykonywano między godziną 6.30 a $19.30 \mathrm{w}$ dni robocze tygodnia. W godzinach tych realizowana jest zdecydowana większość kursów i przewożonych jest około 90\% 
pasażerów. Badania polegały na rejestracji czasów przejazdu oraz zliczaniu pasażerów wsiadających i wysiadających z autobusów na poszczególnych przystankach ${ }^{13}$.

Ruch drogowy w Rzeszowie charakteryzuje się występowaniem dwóch szczytów: porannego $\mathrm{w}$ godzinach $6.30-8.30$ oraz popołudniowego w godzinach $14.00-16.00$. Na rysunko 8 pokazano czasy przejazdu i średnią prędkość całej trasy w wybranym dniu roboczym.

Rys. 8. Parametry przejazdu całej trasy linii 0B w dzień roboczy: a) czas, b) prędkość
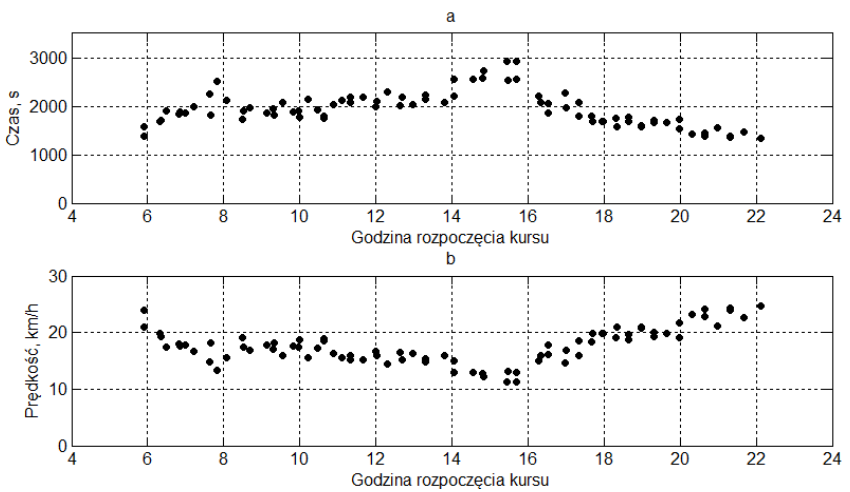

Źródło: opracowanie własne.

Godziny szczytów komunikacyjnych nie charakteryzowały się jednak największymi przewozami na poszczególnych kursach. Dla wybranego dnia 18 listopada 2014 r. przewożona przez autobusy w poszczególnych kursach liczba pasażerów została przedstawiona na rysunku 9a. Dane te dotyczą autobusów kursujących przez cały dzień i nie uwzględniają autobusów dodatkowych. Przebieg linii 0B jest dosyć specyficzny. Wzdłuż trasy znajdują się głównie centra handlowe, szkoły i uczelnie wyższe oraz urzędy. Uwzględniając dane z rysunku 9a oraz dodatkowe kursy wykonywane w godzinach porannych i popołudniowych, sporządzono wykres liczby przewożonych pasażerów w poszczególnych godzinach - przedstawiony na rysunku 9b. Przewozy największej liczby pasażerów występują między godzinami 7.00-15.00. Są to godziny pracy szkół i instytucji publicznych oraz centrów handlowych. Pasażerami w większości są uczniowie, studenci, petenci urzędów i instytucji oraz osoby wybierające się na zakupy.

\footnotetext{
${ }^{13}$ M. Śmieszek, M. Dobrzańska, P. Dobrzański , op. cit.
} 
Rys. 9. Zmierzona i obliczona 18 listopada 2014 r. liczba pasażerów na linii $0 \mathrm{~B}$ a) na poszczególnych kursach, b) w poszczególnych godzinach

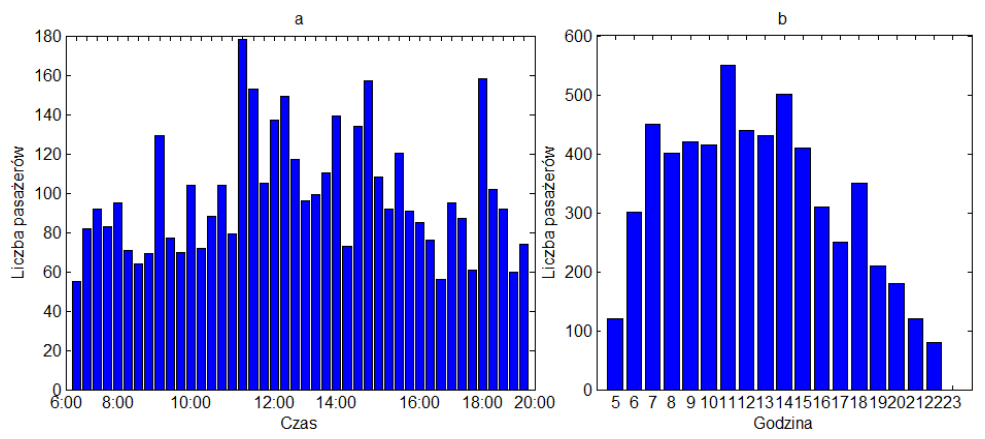

Źródło: opracowanie własne.

$\mathrm{Na}$ rysunku 10a przedstawiono liczbę pasażerów przewiezionych przez rzeszowską komunikację miejską w wybranym dniu powszednim. W analizowanym dniu na wszystkich liniach przewieziono 96,3 tys. pasażerów. Przedstawione na rysunku 10a wartości dotyczą przedziałów półtoragodzinnych. Największa liczba pasażerów korzystających z rzeszowskiej komunikacji miejskiej przypadła na godziny 6.30-8.00 (szczyt poranny) i 14.00-15.30 (szczyt popołudniowy). W niedzielę liczba pasażerów rzeszowskiej komunikacji miejskiej stanowiła 28,5\% liczby pasażerów korzystających z usług rzeszowskiej komunikacji miejskiej w dzień powszedni. Najwięcej pasażerów zostało przewiezionych w godzinach popołudniowych $15.30-18.30$ (rys. 10b) ${ }^{14}$.

Rys. 10. Liczba pasażerów przewożonych przez rzeszowską komunikację miejską: a) w dniu powszednim, b) w niedzielę
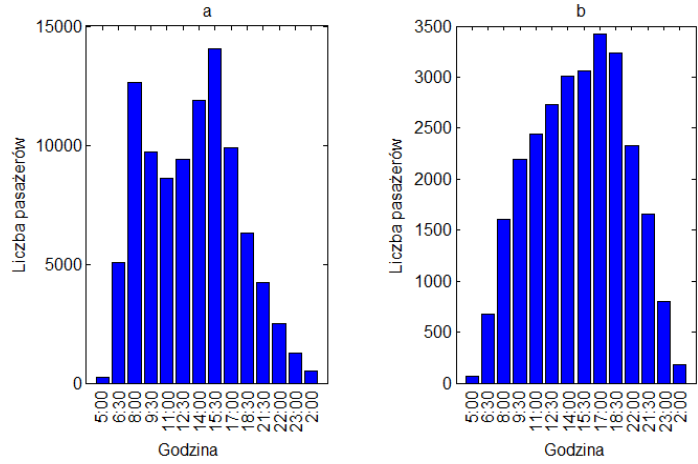

Źródło: opracowanie własne na podstawie http://www.ztm.erzeszow.pl/.

Analizując wykorzystanie środków transportu w Rzeszowie, można stwierdzić, że najczęściej wykorzystywanym środkiem transportu jest samochód osobowy. Był on wykorzystywany w ponad $40 \%$ podróży. Drugie miejsce zajmuje transport zbiorowy, którego udział wynosi ponad 30\%. Dość znaczny udział ponad $20 \%$ stanowią podróże piesze.

\footnotetext{
${ }^{14}$ http://www.ztm.erzeszow.pl/.
} 
Wykorzystanie rowerów w wypadku Rzeszowa jest marginalne i stanowi niespełna 2\% (rys. $11)$.

Rys. 11. Procentowy rozkład pomiędzy różnymi środkami transportu

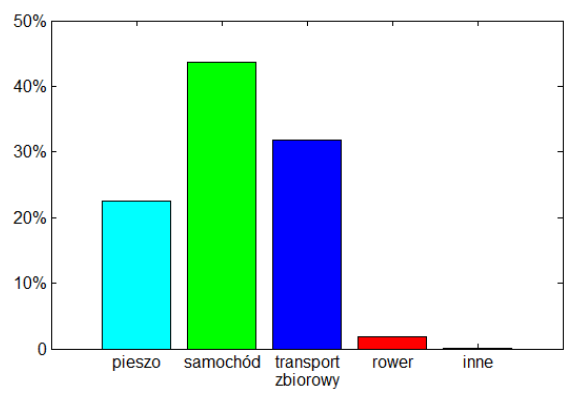

Źródło: opracowanie własne na podstawie http://www.ztm.erzeszow.pl/.

Na rysunku 12 przedstawiono prognozę wskaźnika ruchliwości dla mieszkańców Rzeszowa. W 2014 r. obserwowany był wzrost tego wskaźnika w stosunku do 2009. W kolejnych latach przewiduje się dalszy wzrost tego wskaźnika.

Rys. 12. Prognoza wskaźnika ruchliwości dla mieszkańców Rzeszowa

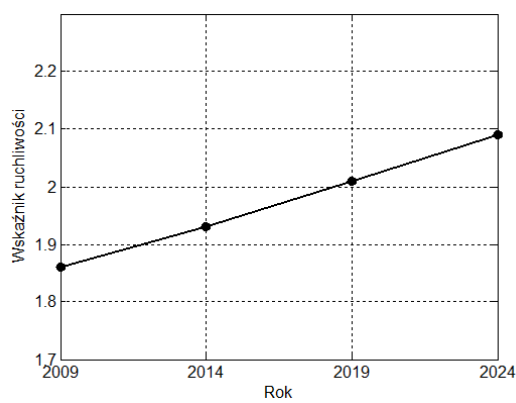

Źródło: opracowanie własne na podstawie http://www.ztm.erzeszow.pl/

4. ANALIZA FUNKCJONOWANIA KOMUNIKACJI MIEJSKIEJ W LINKÖPING

Kolejnym analizowanym miastem jest Linköping. Jest to miasto leżące na południowy wschód od Sztokholmu, nad rzeką Stångån. Jest jednym z najbardziej zaludnionych miast w Szwecji. Miasto liczy 104232 (2010) mieszkańców, a gmina Linköping, około 149906 (2013). Jest to jedna z najszybciej rozwijających się gmin w Szwecji. Linköping jest siódmym co do wielkości miastem w Szwecji. Miasto to jest stolicą regionu administracyjnego Östergötland i zarazem ważnym ośrodkiem gospodarczym, handlowym, przemysłowym, kulturalnym i akademickim. Posiada zróżnicowaną działalność przemysłową (przemysł mechaniczny, lotniczy, sprzętu obronnego, elektroniki i mikroelektroniki, spożywczy). Lokalizacja w centrum regionu i jego doskonała sieć komunikacyjna sprawiły, że Linköping jest krajowym i międzynarodowym centrum biznesu. 
Powierzchnia miasta wynosi $42,16 \mathrm{~km}^{2}{ }^{15}$. Na rysunku 13 przedstawiono liczbę mieszkańców (rys. 13a) oraz zarejestrowanych pojazdów (rys. 13b). W obydwu wypadkach można zauważyć tendencję wzrostową. Pod względem liczby ludności jest to wzrost wynoszący $14 \%$ w latach 2000-2014. Podobnie sytuacja przedstawia się w wypadku liczby zarejestrowanych pojazdów. W okresie 2002-2012 wzrost wyniósł ponad 15\%.

Rys. 13. Wybrane wskaźniki charakteryzujące miasto Linköping a) liczba mieszkańców, b) liczba samochodów osobowych
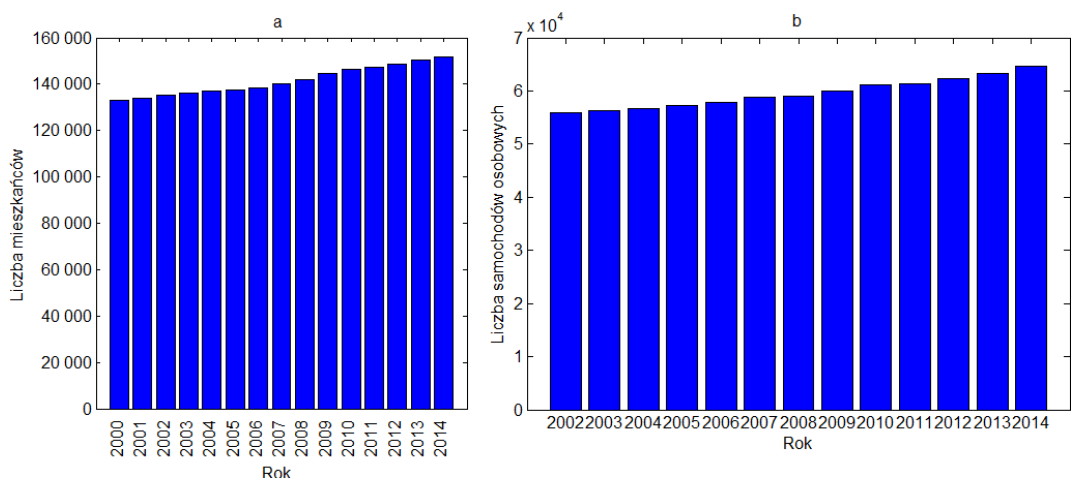

Źródło: opracowanie własne na podstawie: http://www.linkoping.se/.

Transport publiczny w Linköping jest obsługiwany przez regionalnego operatora transportu publicznego AB ÖstgötaTrafiken, który oferuje usługi autobusowe, kolejowe i tramwajowe w całym regionie Östergötland. Podczas gdy pociągi są najczęściej wykorzystywane do dotarcia do sąsiednich miast i miasteczek, autobusy są najbardziej rozpowszechnioną formą transportu publicznego w mieście. Sieć transportowa miasta jest skuteczna i przyjazna dla środowiska. Do zasilania autobusów miejskich wykorzystuje się odnawialne źródło energetyczne - biogaz ${ }^{16}$. Wszystkie linie autobusowe rozchodzą się z dworca głównego. Komunikacja publiczna w Linköping składa się z 29 linii miejskich, wśród których można wyróżnić kilka linii specjalnych, ograniczających się do przewozu uczniów lub pracowników do odpowiednich punktów (szkoły, zakłady pracy). Linie te kursują tylko w wybranych godzinach związanych $\mathrm{z}$ harmonogramem dnia pasażerów (uczniów, pracowników).

W wypadku liczby przewozów komunikacją miejską od 2005 r. jest obserwowany systematyczny wzrost (rys. 14a). Natomiast nasycenie samochodami osobowymi utrzymuje się na zbliżonym poziomie (rys. 14b).

\footnotetext{
${ }^{15} \mathrm{http}: / /$ www.linkoping.se/.

${ }^{16}$ M. Fallde, M. Eklund, Towards a sustainable socio-technical system of biogas for transport: the case of the city of Linköping in Sweden, „Journal of Cleaner Production” 2015/98.
} 
Rys. 14. a) Przewozy komunikacją publiczną i b) nasycenie samochodami osobowymi
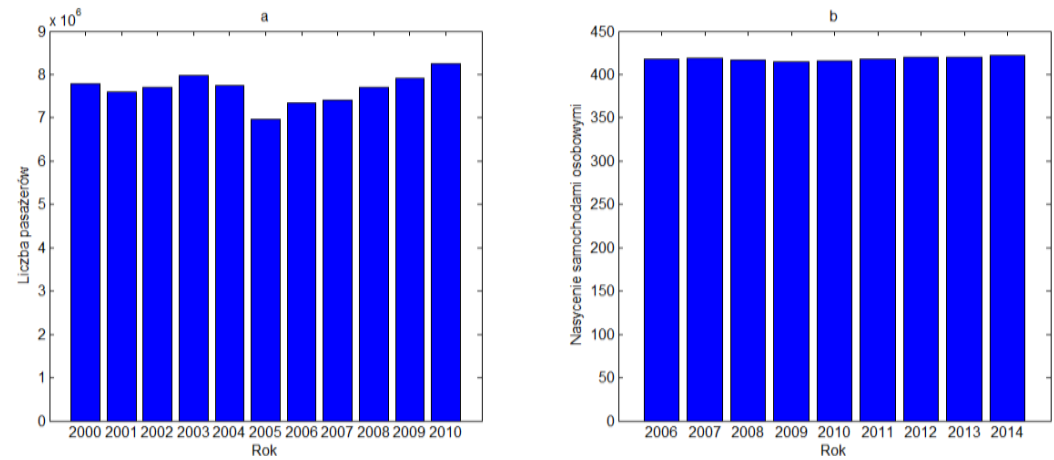

Źródło: opracowanie własne na podstawie: http://www.linkoping.se/.

W wypadku miasta Linköping analizie poddano linię numer 18. Jest to linia o podobnym charakterze do linii 0B w Rzeszowie. Charakteryzuje się również jednokierunkowym ruchem okrężnym wokół centrum miasta. Jej początek i koniec znajdują się na dworcu głównym znajdującym się w centrum miasta. Na trasie linii są 24 przystanki, średnia odległość między sąsiednimi przystankami wynosi około $400 \mathrm{~m}$ (rys. 16a). Na rysunku 15 przedstawiono przebieg linii 18. Wzdłuż trasy przejazdu autobusu znajduje się między innymi szpital uniwersytecki, który zatrudnia 4300 pracowników i posiada 640 łóżek. Na linii kursują autobusy zasilane biogazem. Poszczególne linie charakteryzują się różnymi średnimi prędkościami (rys. 16b). Najniższe wartości osiągają pojazdy kursujące w centrum miasta. Przykładem jest tu analizowana linia 18.

Rys. 15. Przebieg linii 18 na terenie miasta Linköping wraz z umiejscowionymi na jej trasie przystankami

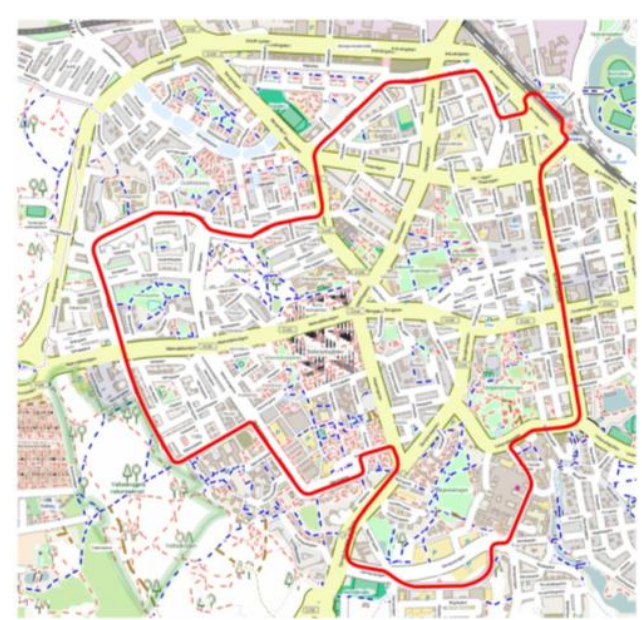

Źródło: opracowanie własne. 
Rys. 16. Wybrane parametry linii komunikacji miejskiej: a) odległości międzyprzystankowe, b) średnie prędkości

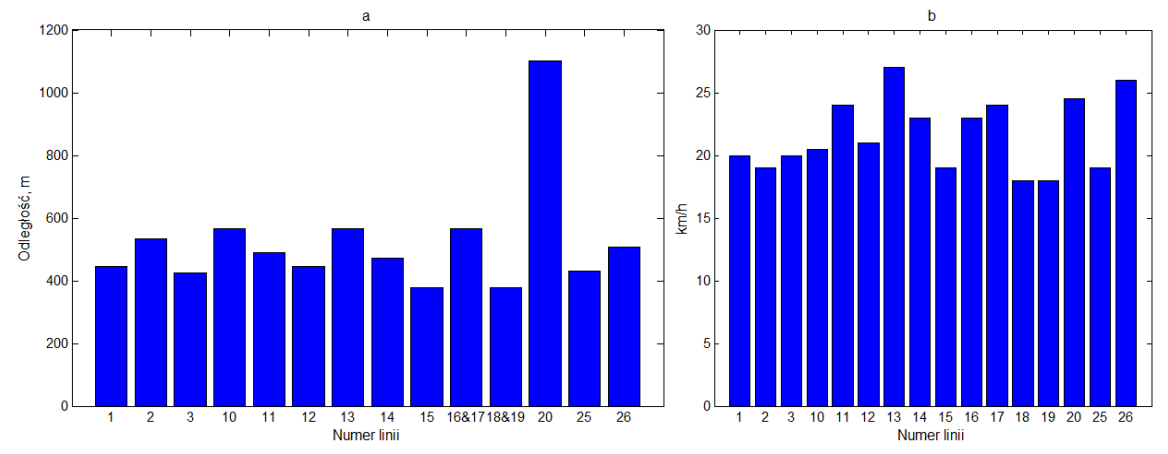

Źródło: opracowanie własne na podstawie http://www.linkoping.se/

Badania dla Linköping przeprowadzono w dni powszednie i weekendy w godzinach 0.00-23.00 ${ }^{17}$. W mieście w dzień powszedni również można wyróżnić dwa szczyty: poranny w godzinach 7.00-8.00 oraz popołudniowy w godzinach 15.00-16.00 (rys. 17a). Natomiast w dni świąteczne można zauważyć jeden szczyt przypadający na godziny 13.00-14.00 (rys. 17b). Można również stwierdzić, że liczba podróżnych w godzinach wieczornych i nocnych jest o wiele wyższa $\mathrm{w}$ weekendy niż $\mathrm{w}$ dni powszednie.

Rys. 17. Zmierzona liczba pasażerów w a) dni powszednie, b) weekendy
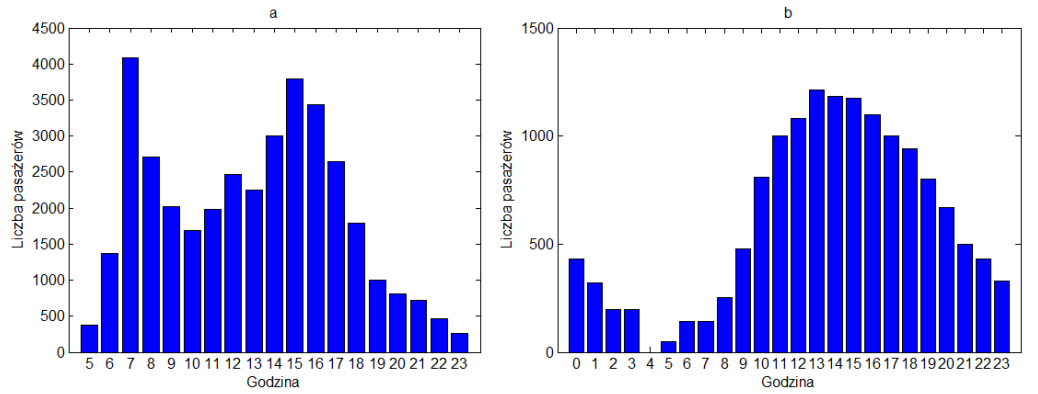

Źródło: opracowanie własne na podstawie http://www.linkoping.se/

Analizując wykorzystanie poszczególnych środków transportu w mieście Linköping (rys. 18), można zauważyć od 1999 r. wzrost udziału wykorzystania samochodów prywatnych. W 2014 r. udział samochodów prywatnych wynosił 64\% i w porównaniu z rokiem 1999 był to wzrost o 7 punktów procentowych. W przypadku wykorzystania jako środka transportu rowerów można z kolei zauważyć w 2014 r. 7 procentowy spadek liczby podróży wykonywanych przy wykorzystaniu tego środka transportu w porównaniu z rokiem 1999. Natomiast transport publiczny utrzymuje się na dość stabilnym poziomie, choć porównując lata 2008 i 2014 można zauważyć 2-procentowy spadek.

\footnotetext{
${ }^{17} \mathrm{http}: / /$ www.linkoping.se/.
} 
Rys. 18. Procentowy rozkład pomiędzy różnymi środkami transportu w dni powszednie

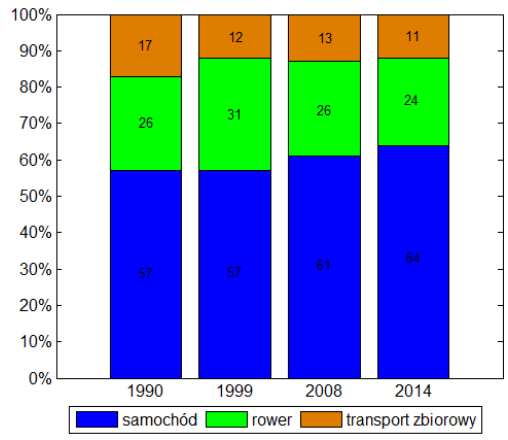

Źródło: opracowanie własne na podstawie http://www.linkoping.se/.

$\mathrm{Na}$ kolejnym wykresie (rys. 19a) przedstawiono liczbę przejazdów, jakie odbyły się w mieście Linköping w badanym okresie. Najniższą liczbę przejazdów można zaobserwować w 2008 r. W porównaniu z rokiem 1999 spadek ten wynosi prawie 8\%. Natomiast w 2014 r. widoczny jest 5-procentowy wzrost liczby przejazdów w porównaniu z 2008. Rozpatrując liczbę przejazdów przypadającą na jedną osobę (rys. 19b), można zauważyć tendencję spadkową. W 1999 r. liczba ta wynosiła 2,8, natomiast 15 lat później 2,3 przejazdu na osobę.

Rys. 19. Liczba przejazdów w dzień powszedni: a) całkowita, b) na osobę
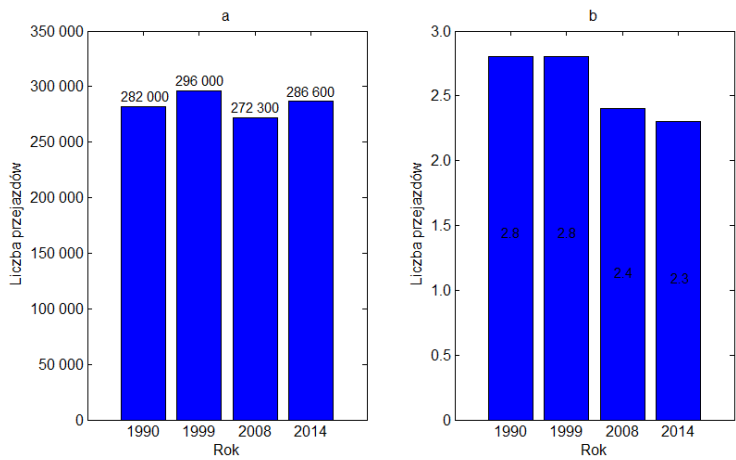

Źródło: opracowanie własne na podstawie http://www.linkoping.se/.

\section{PODSUMOWANIE}

Konieczność ochrony środowiska wymusza podjęcie działań we wszystkich obszarach gospodarczych wykorzystujących źródła energii i emitujących substancje szkodliwe do atmosfery. Jednym $z$ takich istotnych obszarów jest transport pasażerski. W ramach polityki Unii Europejskiej zaleca się rozwój zrównoważonego transportu pasażerskiego i zwiększenie udziału wykorzystania energetycznych surowców odnawialnych. W ramach tych działań dąży się do zwiększenia roli i znaczenia komunikacji publicznej, preferuje się proekologiczne formy transportu w postaci transportu rowerowego oraz prowadzi prace mające na celu wykorzystanie odnawialnych źródeł energii w transporcie miejskim. Wszystkie te zalecenia wprowadzane są w poszczególnych krajach członkowskich. Stopień ich realizacji w 
poszczególnych krajach nie jest jednakowy. Zmiany te w dużym stopniu zależą od poziomu świadomości proekologicznej społeczeństwa oraz od osiągniętego dochodu narodowego.

$\mathrm{W}$ celu pokazania tych różnic $\mathrm{w}$ artykule przedstawiono politykę transportową realizowaną przez dwa miasta z państw UE o różnych stopniach rozwoju gospodarczego. Jednym z nich jest Linköping. Ze względu na osiągnięty poziom rozwoju gospodarczego i wprowadzonych zmian w komunikacji publicznej miasto to zostało użyte jako wzorzec określający kierunki zmian. Nasycenie pojazdami prywatnymi praktycznie nie zmienia się w nim już od kilku lat $\mathrm{i}$ można przyjąć, że osiągnęło już maksymalny poziom. Cała działalność władz miasta w dziadzinie ochrony środowiska skupia się na pozostałych formach transportu publicznego, do których można zaliczyć transport zbiorowy i rowerowy. Rzeszów jest miastem o znacznie niższym poziomie dochodów mającym aspiracje $\mathrm{w}$ niedalekiej przyszłości zbliżenia się do poziomu miast zachodniej Europy. Poziom nasycenia pojazdami samochodowymi osiągnął już stan Linköpingu. Natomiast w innych obszarach działalności transportowej występują duże różnice. W wypadku transportu zbiorowego wszystkie autobusy szwedzkie napędzane są ekologicznym paliwem pochodzącym z odnawialnych źródeł energetycznych. W Rzeszowie większość pojazdów komunikacji zbiorowej wykorzystuje olej napędowy. Udział ekologicznego paliwa CNG w pracy przewozowej autobusów zbliża się do poziomu $40 \%$. Obszarem, w którym występuje największa dysproporcja pomiędzy dwoma miastami, jest transport rowerowy. Udział transportu rowerowego w Linköpingu sięga 24\%. W Rzeszowie udział transportu rowerowego jest raczej marginalny, a przejażdżki rowerowe wykorzystywane są głównie do celów rekreacyjnych. Problem ten jest dostrzegany przez władze miasta. W mieście powstają nowe trasy rowerowe, wypożyczalnie rowerów miejskich oraz jest prowadzona polityka zachęcająca mieszkańców do korzystania z tej formy transportu.

\section{LITERATURA}

[1] EU transport in figures, Statistical Pocketbook 2014.

[2] EU transport in figures, Statistical Pocketbook 2015.

[3] European Commission Report Brussels, 17.12.2013COM (2013) 913 final.

[4] Fallde M., Eklund M., Towards a sustainable socio-technical system of biogas for transport: the case of the city of Linköping in Sweden, ,Journal of Cleaner Production" 2015/98, s. 17-28.

[5] http://ec.europa.eu/eurostat.

[6] http://stat.gov.pl/.

[7] http://www.linkoping.se/.

[8] http://www.ztm.erzeszow.pl/.

[9] Mussone L., Grant-Muller S., Laird J., Sensitivity analysis of traffic congestion costs in a network under a charging policy, „Case Studies on Transport Policy” 2015/3, s. 44-54.

[10] Prud'homme R., Koning M., Lenormand L., Fehr A., Public transport congestion costs: The case of the Paris subway, „Transport Policy 2012/21, s. $101-109$.

[11] Śmieszek M., Dobrzańska M., Dobrzański P., Analiza czasów przejazdu wybranej linii komunikacji miejskiej w Rzeszowie, „Logistyka” 2015/4, s. 6131-6137. 


\section{ANALYSIS OF CHANGES IN PUBLIC TRANSPORT OF THE EUROPEAN}

UNION ON THE EXAMPLE OF SELECTED CITIES

Transportation needs are secondary needs of a man and are associated with different spatial distribution of resources, human settlements and places of work. Economic development is closely linked to the transport infrastructure and transport capacity. Transportation applies to both cargo movement and population. In the cities, especially important is the transport of people, often referred to as public transport. Urban development, both in terms of population and the surface, generates an increase in transport needs. In addition, economic development requires more and more active people and their mobility. Urban passenger transport is largely based on private cars with a conventional drive system. An increasing number of travels by those means of transport contributes to congestion and an increase of air pollution in urban areas through gas emissions from the combustion of petroleum products. Both of these factors and the noise caused by vehicle traffic contribute to a reduction in quality of life. One way to reduce these negative trends is to switch to more sustainable mobility, which is the collective passenger transport. This approach is consistent with the current guidelines of the European Union aimed at protecting the environment and saving of primary energy sources that promote the development of sustainable transport and renewable energy. The main aim of this article is to present the changes in the functioning of passenger transport in the European Union, and to show, on the example of two selected medium-sized cities, the degree of implementation of transport policy aimed at the development of sustainable urban transport.

Keywords: public transport, transport policy, organization of public transport.

DOI:10.7862/rz.2016.hss.9

Przesłano do redakcji: styczeń 2016

Przyjęto do druku: maj 2016 